\title{
Challenges and Dilemmas for Dental Undergraduate Teaching with the Advent of COVID-19
}

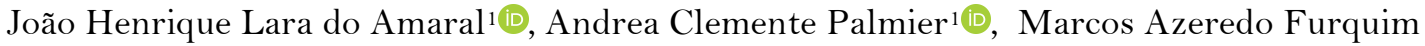 \\ Werneck ${ }^{1}\left(\mathbb{D}\right.$, Simone Dutra Lucas ${ }^{1}$, Maria Inês Barreiros Senna ${ }^{2}(\mathbb{D}$
}

\begin{abstract}
${ }^{1}$ Department of Social and Preventive Dentistry, School of Dentistry, Federal University of Minas Gerais, Belo Horizonte, MG, Brazil. ${ }^{2}$ Department of Oral Surgery, Oral Medicine and Oral Pathology, School of Dentistry, Federal University of Minas Gerais, Belo Horizonte, MG, Brazil.
\end{abstract}

Correspondence: Marcos Azeredo Furquim Werneck, Universidade Federal de Minas Gerais, Odontologia Social e Preventiva, Av. Antônio Carlos, 6627, Pampulha, Belo Horizonte, Minas Gerais, Brazil. 31270-901. E-mail: mfurquim52@gmail.com

Academic Editor: Yuri Wanderley Cavalcanti

Received: 23 June 2020 / Review: 01 August 2020 / Accepted: 22 October 2020

How to cite: Amaral JHL, Palmier AC, Werneck MAF, Lucas SD, Senna MIB. Challenges and dilemmas for dental undergraduate teaching with the advent of COVID-19. Pesqui Bras Odontopediatria Clín Integr. 2021; $21: e 0147$. https://doi.org/10.1590/pboci.2021.067

\begin{abstract}
Since the 1980s, the development of neoliberalism has been observed in Brazil, which has led to the progressive weakening of public policies (including those of education) and the population's impoverishment. In the field of education, there was an increase in the privatization of higher education, inadequate to the requirements of national development, characterizing it more as a commodity than as a right. This article aims to discuss some challenges, risks, and possible strategies to face the impact of the COVID19 pandemic in undergraduate dental education. This pandemic had an immediate and dramatic impact on dental education in more than 130 countries, prompting teachers and students to adopt remote teaching activities. In Brazil, theoretical classes were offered remotely, mainly in private institutions where there was an intensification of academic work for both teachers and students. This process requires support in technological and pedagogical aspects, including tools, resources, and training courses. In the resumption of clinical education, changes in biosafety actions are being proposed to preserve the health of the actors involved. The application of these measures will imply a great mobilization of students, teachers, and technicians and extra attention so that the constitutive dimensions of the teaching-learning process in health are not minimized or forgotten.
\end{abstract}

Keywords: Oral Health; Education, Dental, Graduate; Public Health. 


\section{Introduction}

Brazil presents a scenario of uncertainties in which the advance of the COVID-19 pandemic and the predictions of economic recession reveal the consequences of the adoption of the neoliberal political model, which bets on the minimal state and weakens public social policies facing a situation of high-income concentration, increased social vulnerability and the risk of sickness for a significant portion of the population [1].

The adoption of neoliberal policies in Brazil began under the Collor de Melo government and progressed under the Fernando Henrique Cardoso administration, with the main resources being a containment of public spending and privatizations, revealing a low investment by the Brazilian State in public policies, increasing the income concentration and poverty. Neoliberalism remained in the Lula and Dilma Rousseff governments. However, in this period, a significant investment has been observed in the fight against hunger and misery and the adoption of inclusive social policies, some of which are compensatory, in the fields of health, education, and work. It was twelve years of relative stability in the economy and job recovery. However, in the year 2015, signs of weakening of the economy appeared [2].

In 2016 with Dilma Rousseff's impeachment, Temer took over the presidency and presented the country with a government plan that signaled the resumption of cost containment and privatizations. In a short time, a process of de-democratization and post-democratic reality was institutionalized, whose intentionality: a) led to the emptying of democracy and the elimination of conflict through neoliberal discourse; b) signaled the opposition to inclusive social policies and social participation; c) it generated disinterest, individualism, consumerism, and depression, which have led to intolerance and violence; d) it was characterized by the "post-truth" that, from denialism, occultism, historical falsification and hatred, misinforms and confuses; e) opened space for the advancement of fundamentalism, generating a scenario in which the privatization of life and the deconstruction of the public practically encounter no resistance [3].

With these characteristics, it was instituted in the Brazilian State, what is called discretionary neoliberalism, whereby the principles:

... integrationists and social democrats (health and education as fundamental rights, universalist conception of service to the population with state policies, etc.) make room for typically neo-liberal conceptions (reduction of public spending, fiscal balance, guaranteeing confidence of market agents, etc. ) [2].

Once more, social policies are no longer configured as a right and are perceived as expenditures for the government. The State is now conceived to give incentive for private initiative, and it should prioritize the transfer of all possible infrastructure to the private sector [2].

Thus, there is a strengthening of the interest of financial capital in the privatization of higher education in educational policies, which perceives it as a commodity and not as a right [4]. This distorted perception is opposed to the need for a higher, qualitative and quantitative training of staff, focused on the construction of democracy, adequate to national development requirements, promoting its immersion in local contexts, projecting the University as an ethical paradigm [5].

The Temer government directed public policies towards the weakening of social areas, including Education and Health, the reduction of social inclusion and the withdrawal of rights, with the approval of Constitutional Amendment No. 95 (EC 95), which froze, from 2017, the federal budget of these policies for 20 years [6] and defined that the saved resources would be used to pay the public debt [7]. EC 95 reduced the 
State and prevented the constitutional social protection system, including the scrapping of public education and the Unified Health System (SUS), from adequately meeting the population's needs [8].

From the 1980 s onwards, there was a progressive movement towards the privatization of higher education, subsequently favored by the Law of Directives and Bases of National Education (LDB / 96) [9]. During this period, there was an expressive expansion of private dental courses, especially in the North, Northeast, and Midwest regions, accompanied by the internalization of supply in medium and small population municipalities in the interior of the states [10]. Between 2015 and 2019, the number of dental courses grew by $87 \%$, from 220 to $412[11]$.

In Brazil, from 2019, the Ministry of Education presented, as main characteristics, the combat against left-wing ideology, "cultural Marxism” and "progressism" in education, the subordination of the cathedra and the didactic-pedagogical and administrative autonomies, combined with the scrapping of Federal Higher Education Institutions (FHEI), through continuous budget cuts. The "Future-se Program" was also proposed, with a clear intention to deepen the opening of public universities to the private sector [12].

In this complex scenario, reflections on the dental undergraduate teaching emerge, added by the uncertainties of the pandemic of COVID-19, which imply questions for the areas of Education and Health, whose dialogue and interdependence are fundamental for the training of health professionals. This article proposes to discuss some challenges, risks and possible strategies to face the impact of the pandemic of COVID 19 in undergraduate dental education.

\section{Weaknesses and Immediate Implications of Coronateaching}

The COVID-19 pandemic in the oral health field imposed a strong mobilization on international organizations, control and promotion research agencies, health services and educational institutions for its combat. It had an immediate and dramatic impact on dental education in more than 130 countries. To better understand this situation, the immediate experiences adopted in several countries will be approached in a critical analysis of what was developed, and some perspectives for overcoming the problems experienced by teachers and students will be outlined.

Most dental schools in the United States and many in Europe have adopted remote teaching activities. Institutions, coordinators, teachers and students were asked to adapt quickly to an urgent supply of online courses. Teachers are being challenged to shift their teaching methods and students to adapt to remote classroom platforms. Simply making course materials available via digital platforms is not the best way to teach students. We agree that "Zoom University is not an adequate online learning" These new methodologies have generated anxiety among teachers and students who need to adjust to new educational methods [13-16].

China involved large technology companies in providing access to content and communication platforms to teachers and students, at all educational levels, through remote classes, television programs broadcast on state TV, apps, and virtual platforms [17]. During the COVID-19 pandemic, about 90\% of European dental schools were using online pedagogical software tools, with $72 \%$ using live videos or broadcasting links to other online materials (48\%), organization of virtual meetings (65\%), and also less frequently work groups, social media groups, among others [14].

The declaration of public health emergency and the collective measures adopted to combat it, such as social isolation and social distance, led to the suspension of face-to-face activities in Higher Education Institutions (HEI) in Brazil. In this context, the Ministry of Education has exceptionally authorized the suspension of face-to-face activities and their replacement by remote classes mediated by Information and 
Communication Technologies (ICT) in all undergraduate courses, except professional internship training practices and laboratory [18-20].

Brazilian HEIs maintained their activities remotely, with the theoretical classes of undergraduate courses being offered, mainly in private institutions where there has been an intensification of academic work for both teachers and students. Teachers started to record video lessons, hold conferences, develop evaluative activities for online application of the contents taught.

It is necessary to consider the differences between emergency remote education and Distance Learning (DL) as the provision of quality DL requires previous and careful planning and an adequate structure. In the days of COVID-19, it is not possible to expect that professionals who have never worked with distance education will be able to do it properly. Although the focus is always on impacts on students, the teachers also suffer significant effects in the workplace. There are many teachers who, without previous experience in Distance Learning and without having enough time for the institutions to train them properly, have appropriated all non-face-to-face media to develop what has been called emergency Distance Learning, transforming classroom format lessons into virtual mode; but without changing the curriculum or the methodology. This abrupt entry into a complex teaching modality, with multiple technological options, can result in sub-ideal results, frustration and oppression due to the adaptation to an educational modality never before experienced, and can generate feelings of helplessness due to the lack of know-how to the operation of platforms and digital resources. For this reason, this process requires external support in technological and pedagogical aspects, including tools, resources, and training courses [21,22].

It is not possible to expect that students who do not have good internet support, computers with a text editor and good processors will develop their class activities properly. A problem frequently experienced, either in Brazil as in other countries, is the low availability of computers for students in their homes for synchronous activities, given that many members of their families are also developing online activities. In Brazil, almost a third of students from schools located in urban areas do not have any computer at home (tablet, laptop, or desk). Among students using the Internet, $18 \%$ access the network exclusively by cell phone, with its great limitations such as interface, cost, speed and stability [15,16,23].

The data from a recent survey on the main problems faced by students worldwide during the pandemic point to the lack of equipment for internet access, internet connection, social isolation, communication with colleagues and teachers, the maintenance of regular schedules for the development of activities, anxiety about COVID-19 and financial concerns, especially when students study in different places from where their families live [22].

In order to face the mentioned problems, as in other countries, urgent measures are needed by the government for public universities and by private educational institutions to overcome the problems of connecting to the Internet and offering adequate equipment, mainly for the poorest students, given that there are currently a significant number of them in universities. Teacher training is also necessary to prepare teaching materials, as it is not enough to simply make the classes previously taught in the classroom available.

Given this scenario, some doubts arise: How will the future of classroom activities and clinics be, since the classes of students generally have a large number of students? How will the internships look, considering that the theoretical / practical subjects ended the semester having taught only the theoretical part in some institutions? It seems that emergency remote education signals the simultaneous offer of presential and distance learning. 


\section{COVID-19: Implications for Clinical Dental Teaching}

In the resumption of clinical education, changes are being proposed in biosafety actions to preserve the health of the actors involved in the professional training of the Dental Surgeon (DS): students, teachers, technical staff, and patients [24-26]. Despite the urgency and relevance of these initiatives, there is always the risk of shifting attention exclusively to the consequences of COVID-19 on these subjects' health, making them forget or minimize important dimensions of the dental teaching and health care process.

In this sense, Santos [27], when referring to what is expected of the University in the 21 st century, signals, among other challenges, the need to reinforce the institution's social responsibility. He states that society is not an abstraction and that these challenges depend on how the University is inserted [27] Therefore, to contextualize the formation of the dental surgeon in the current sanitary conditions of the country is to respond to a demand from Brazilian society, since, according to the National Curricular Guidelines (NCG), "the essential contents for the Undergraduate Dental Course must be related to the whole health-disease process of the citizen, of the family and the community, integrated with the epidemiological and professional reality" [28]. The NCG immediately refers to considering the world of work as a condition for professional training and health production. In turn, work, as an educational principle, is not the exercise of a didactic technique in the sense of learning by doing but an ethical-political principle. However, this does not invalidate the dimension of work as a practical exercise for learning a profession [29].

In the work process at the clinic, the dental surgeon has at his disposal three sets of technologies that allow his intervention on the intercession that is established between him and the patient: hard technologies (equipment and supplies), soft-hard technologies (structured knowledge), and soft technologies (listening, sheltering, protagonism of the subjects) that favor meetings and relational aspects between professionals and patients. These technologies accentuate live work in action, thus understood as the action of the professional at the moment in which he works. The different modes of health production are established according to the combinations that are made of these three types of technologies. In this sense, it is necessary to establish what energy we incorporate in the work process. The energy of norms and procedures that promote the capture of live work or the energy of live work in an act that enhances escape lines as alternatives to the instituted processes [30]. To the experiences of oral health care, with a predominance of hard and soft-hard technologies, it is necessary to oppose another clinic led by soft technologies.

The emergence of COVID-19 highlights the need for strong investment in hard technologies. If, in the conditions prior to the pandemic, the dental practice was already strongly structured in procedures, shifting technological arrangements to an articulation between hard and soft-hard technologies, the greater the risk of losing the relational dimension between professionals and patients. Another result of the incorporation of additional technologies to biosafety procedures is the increase in the costs of providing services. A similar impact will occur in Dental courses, burdening public and private HEI and students.

Pedagogical mediation in teaching will not be spared by restructuring the work process in clinical learning. As part of the clinical activity, with teacher supervision, a strict control of the biosafety rules will be necessary, which can reinforce the centrality of the clinical act. Although necessary, these technologies tend to be hegemonic concerning soft technologies, which will require a greater mobilization of energies for live work. In these conditions, we understand that students and teachers' workload will be intensified with a loss of quality in pedagogical mediation and learning.

The sheltering and assessment of patients' health conditions before clinical care, presential or remotely, will be a critical component in Dental courses. In this procedure, it is necessary to consider the 
patient not as a potential source of infection but as an individual covered by the right to health. Possibly, that individual may be a potential transmitter of the new coronavirus. In shelters, the establishment of attachment is essential for the dialogue between the sheltered and those who shelter him and presupposes recognizing the patient protagonism about their health [31]. Besides, considering the insertion of the patient in the territory is essential for defining this activity. Obtaining signs and symptoms and other information that indicates a possible infection may not be the only items to be registered, but they should compose, with other questions, a set of information about living conditions and health needs. Understanding the importance of sheltering should be shared by the team and reaffirmed as an attitude of all actors involved in clinical care.

\section{The Reinvention of Practices and Internships in Primary Health Care}

Immediately, two questions arise for the curricular internships in SUS: the first, the definition and implementation of Primary Health Care (PHC) strategies against COVID-19, and the second, the protection and health care of the actors who work in the teaching-service-community integration. The approach to these questions is supported by the co-responsibility of the HEIs with public policies with the scenarios of internships and the population's health needs. The resumption and reinvention of the teaching of Dentistry in the fields of internships in PHC is a task to be shared by the HEIs and the SUS [32]. Actors in this construction are teachers and students, managers and service workers and the community. At that moment, it is imperative to resume the DCN of Dental undergraduate courses and reaffirm the scenarios and work processes in SUS as indispensable conditions for the formation of the dental surgeon [28].

\section{Working Conditions of the Subjects Involved in the Formation of the Dental Surgeon}

Regarding the significant impact on the work process of the technical staff, teachers, and students in Dental courses, there is the challenge of knowledge and control of these actors over the work process and environments where they work. As well as the community served, these subjects are invested with the right to health.

In addition to the political dimension of co-participation and co-responsibility of the subjects with their work conditions, it is necessary to observe the care with occupational health. In studies with dental teachers, signs of emotional exhaustion associated with interpersonal relationships and intensification of teaching work were identified [33,34]. Among dental students, Neves and Ribeiro [35] reported Burnout Syndrome's presence in 10, $89 \%$ of students from a public HEI. The syndrome was associated, among other factors, with more intense class hours. Faced with this scenario, however great the efforts to achieve ideal biosafety conditions in the face of COVID-19, it is worrying the addition of yet another condition of emotional and physical stress for teachers, students, technical staff and patients. In this sense, it is proposed: the incorporation of detailed information about coronavirus infections and strategies for coping with the course, sharing this information with technical staff and patients, structuring mental health support services, implementing pandemic surveillance in HEIs, and regular production of epidemiological bulletins.

\section{Final Considerations}

COVID-19 emerged when the Brazilian State was adopting discretionary neoliberalism, which gave public policies a new meaning, removing the sense of right and assigning them the value of "expenses", implying their transfer to the private sector. This includes university education. 
It is possible that university education in health in Brazil was not prepared to face the challenges that arose and to organize itself to prevent the abrupt arrival of COVID-19 from being so surprising that it did not guarantee its clarity and the know-how to face its consequences.

It is essential to be aware of the limits of emergency remote education and the importance of Distance Learning being developed with the potential to qualify to teach and enable the adoption of a hybrid model. Both cannot do without a rigorous planning process where, in addition to being clear about their limits and differences, are appropriate to the objectives of education, they have agile, sufficient and democratic technical support, allowing access for all involved. It is also important to be clear about the temporary nature of remote education to prevent it from being used as an argument to force the substitution of the face-to-face classes and relational character that higher Dental education requires as a fundamental component in the training of dental surgeons.

Undergraduate Dental courses have a significant practical workload in clinical settings as the main characteristic, which requires a careful study to postpone or propose substitute teaching methods while the COVID-19 pandemic lasts. It means discussing, with caution, the organization of teaching in clinical settings, using scientific and technological resources for equipment, physical space, and work process to humanize relationships and enable quality and safe teaching for users.

The COVID-19 pandemic opens up, for dental education, the possibility of strengthening training for public health, with the insertion of theoretical, practical contents and experiences in teamwork in Unified Health System, on the conceptual basis of interprofessionality. It is important to reinforce the constitutional role of Unified Health System as the organizer of health education in Brazil. Its weakening due to Constitutional Amendment No. 95 may make the innumerable internships and practices that occur in Unified Health System scenarios unfeasible.

\section{Authors' Contributions}

\begin{tabular}{|c|c|c|}
\hline JHLA (D) & https://orcid.org/0000-0001-6900-7559 & Conceptualization, Methodology and Writing - Original Draft. \\
\hline $\mathrm{ACP}$ & https://orcid.org/0000-0001-8943-6836 & Conceptualization, Methodology, Formal Analysis, Investigation and Writing - Original Draft. \\
\hline MAFW (iD) & https://orcid.org/0000-0002-4160-018X & Conceptualization, Investigation, Writing - Review and Editing and Supervision. \\
\hline SDL (iD) & --- & Conceptualization, Methodology, Investigation and Writing - Review and Editing. \\
\hline MIBS (D) & https://orcid.org/0000-0002-0578-8744 & Conceptualization, Methodology, Investigation and Writing - Review and Editing. \\
\hline
\end{tabular}

\section{Financial Support}

None.

\section{Conflict of Interest}

The authors declare no conflicts of interest.

\section{Data Availability}

The data used to support the findings of this study can be made available upon request to the corresponding author.

\section{References}

[1] The Lancet. COVID-19 in Brazil: "So what?". Lancet 2020; 395(10235):1461. https://doi.org/10.1016/So140-6736(20)31095-3

[2] Maia LA. PEC-55 e o neoliberalismo discricionário no Brasil. Rev Despierta 2016; 3(3):52-76. [In Portuguese].

[3] Ballestrin L. Pós-democracias no sul global e melancólica desdemocratização no Brasil contemporâneo. 2017. Available from: https://www.justificando.com/2017/11/23/pos-democracias-no-sul-global-e-melancolicadesdemocratizacao-no-brasil-contemporaneo/ [Accessed on May 28, 2020]. 
[4] Almeida Filho N. The brazilian university in a globalized context of marketization of higher education: colleges vs. vikings. Rev Lusófona de Educação 2016; 32(32):11-30.

[5] Mello AF, Almeida Filho N, Ribeiro RJ. For a socially relevant university. Atos Pesqui Educ 2009; 4(3):292-302.

[6] Brasil. Governo Federal. Emenda Constitucional no 95, de 15 de dezembro de 2016. Altera o Ato das Disposições Constitucionais Transitórias, para instituir o Novo Regime Fiscal, e dá outras providências. Brasília: Diário Oficial da União, 2016. Available from: https://www.in.gov.br/materia//asset_publisher/KujrwoTZC2Mb/content/id/2 1295527/do 1-2016-12-16-emenda-constitucional-n-95-2 1295459 [Accessed on May 28, 2020]. [In Portuguese].

[7] Matuoka I. O impacto do teto de gastos sobre as políticas de educação. 2017. Available from: https://educacaointegral.org.br/reportagens/o-impacto-do-teto-de-gastos-sobre-as-politicas-de-educacao/ [Accessed on May 23, 2020]. [In Portuguese].

[8] Souza MB, Hoff TSR. Governo Temer e a volta do neoliberalismo no Brasil: possíveis consequências para a habitação popular. urbe. Rev Bras Gestão Urbana 2019; 11 :e20180023. https://doi.org/10.1590/2175-3369.011.e20180023

[9] Brasil. Lei no 9.394/96, de 20 de dezembro de 1996. Estabelece as diretrizes e bases da educação nacional. Brasília: Diário Oficial da União, 1996. Available from: https://www.planalto.gov.br/ccivil_03/leis/19394.htm [Accessed on July 22, 2020]. [In Portuguese].

[10] Oliveira BLCA, Lima SF, Pereira MUL, Pereira Júnior GA. Evolution, distribution and expansion of medicine courses in Brazil (1808-2018). Trab Educ Saúde 2019; 17(1):e0018317. https://doi.org/10.1590/1981-7746-solo0183

[11] Conselho Federal de Odontologia. CFO reforça necessidade do Ministério da Educação suspender autorizações para abertura de novos cursos de odontologia. Available from: https://website.cfo.org.br/cfo-reforca-necessidade-doministerio-da-educacao-suspender-autorizacoes-para-abertura-de-novos-cursos-de-odontologia/. [Accessed on July 20, 2020]. [In Portuguese].

[12] Barone I. Como ficou o plano de Bolsonaro para afastar a influência da esquerda na educação. 2019. Available from: https://www.gazetadopovo.com.br/republica/o-que-bolsonaro-fez-na-educacao-2019/ [Accessed on May 24, 2020]. [In Portuguese].

[13] Iyer P, Aziz K, Ojcius DM. Impact of COVID-19 on dental education in the United States. J Dent Educ 2020; 84(6):15. https://doi.org/10.1002/jdd.12163

[14] Quinn B, Field J, Gorter R, Akota I, Manzanares MC, Paganelli C, et al. COVID-19: The Immediate response of european academic dental institutions and future implications for dental education. Eur J Dent Educ 2020; 10.1111/eje.12542. https://doi.org/10.1111/eje.12542

[15] Nóbrega AC. A universidade federal brasileira, a pandemia da Covid-19 e além! 2020. Available from: https://www.andifes.org.br/a-universidade-federal-brasileira-a-pandemia-da-covid-19-e-alem/. [Accessed on June 19, 2020]. [In Portuguese].

[16] Witze A. Universities will never be the same after the coronavirus crisis. Nature 2020; 582:162-4. https://doi.org/10.1038/d41586-020-01518-y

[17] Arruda EP. Emergency remote education: elements for public policies in Brazilian education in Covid-19 times. EmRede 2020, 7(1):257-75.

[18] Brasil. Ministério da Educação. Portaria MEC-GM nº 343, de 17 de março de 2020. Dispõe sobre a substituição das aulas presenciais por aulas em meios digitais enquanto durar a situação de pandemia do Novo Coronavírus - COVID19. Brasília: Diário Oficial da União, 2020. Available from: https://www.in.gov.br/en/web/dou/-/portaria-n-343-de17-de-marco-de-2020-248564376 [Accessed on May 28, 2020]. [In Portuguese].

[19] Brasil. Ministério da Educação Portaria n ${ }^{\circ} 473$, de 12 de maio de 2020 . Prorroga o prazo previsto no $\S 1^{\circ}$ do art. $1^{\circ}$ da Portaria $\mathrm{n}^{\circ}$ 343, de 17 de março de 2020. Brasília: Diário Oficial da União, 2020. Available from: https://abmes.org.br/arquivos/legislacoes/Portaria-mec-473-2020-05-12.pdf [Accessed on May 28, 2020]. [In Portuguese].

[20] Brasil. Ministério da Educação Portaria n 544, de 16 de junho de 2020. Dispõe sobre a substituição das aulas presenciais por aulas em meios digitais, enquanto durar a situação de pandemia do novo coronavírus - Covid-19, e revoga as Portarias MEC n 343, de 17 de março de 2020, $n^{\circ}$ 345, de 19 de março de 2020c, e $\mathrm{n}^{\circ}$ 473, de 12 de maio de 2020. 2020. Available from: https://www.in.gov.br/en/web/dou/-/portaria-n-544-de-16-de-junho-de-2020261924872 [Accessed on June 18, 2020]. [In Portuguese].

[21] Jesus SC. Educação e tecnologias digitais em tempos de pandemia. In: Grossi MP, Toniol R. Cientistas sociais e o coronavírus. Associação Nacional de Pós graduação em Ciências Sociais. Boletim n.41; 2020. Available from: https://anpocs.com/images/stories/boletim/boletim_CS/Boletim_n41.pdf [Accessed on May 28, 2020]. [In Portuguese].

[22] UNESCO. COVID-19 y educación superior: de los efectos inmediatos al día después - Análisis de impactos, respuestas políticas y recomendaciones. 2020. Available from: https://www.iesalc.unesco.org/wpcontent/uploads/2020/05/COVID-19-ES-130520.pdf [Accessed on June 08, 2020]. [In Spanish].

[23] Flores N, Arnt A. Desigualdade Social e Tecnologia: o ensino remoto serve para quem? 2020. Available from: https://www.blogs.unicamp.br/covid-19/desigualdade-social-e-tecnologia-o-ensino-remoto-serve-para-quem/ [Accessed on June 06, 2020]. [In Portuguese]. 
[24] Peng X, Xu X, Li Y, Cheng L, Zhou X, Ren B. Transmission routes of 2019-nCoV and controls in dental practice. Int J Oral Sci 2020; 12(9):1-6. https://doi.org/10.1038/s41368-020-0075-9

[25] Fini MB. What dentists need to know about COVID-19. Oral Oncol 2020; 105:104741. https://doi.org/10.1016/j.oraloncology.2020.104741

[26] Brasil. Agência Nacional de Vigilância Sanitária. Nota Técnica GVIMS/GGTES/ANVISA Nº 04/2020 Orientações para Serviços de Saúde: Medidas de Prevenção e Controle que Devem ser Adotadas Durante a Assistência aos Casos Suspeitos ou Confirmados de Infecção pelo Novo Coronavírus (SARS-COV-2). Atualizada em 31/03/2020. Available from: https://portal.anvisa.gov.br/ [Accessed on May 28, 2020]. [In Portuguese].

[27] Santos BS. A Universidade no Século XXI. 2. ed. Rio de Janeiro: Cortez Editora, 2005. 120 p. [In Portuguese].

[28] Brasil. Ministério da Educação. Conselho Nacional de Educação / Câmara de Educação. Resolução CNE/CES nº 3/2002, de 19 de fevereiro de 2002. Institui Diretrizes Curriculares Nacionais do Curso de Graduação em Odontologia. Brasília: Diário Oficial da União, 2002. Available from: https://portal.mec.gov.br/cne/arquivos/pdf/CES032002.pdf [Accessed on May 28, 2020]. [In Portuguese].

[29] Frigotto G. Trabalho. In: Pereira IP, Lima JCF. Dicionário da Educação Profissional em Saúde. Rio de Janeiro: Fiocruz, Escola Politécnica de Saúde Joaquim Venâncio; 2006. p. 258-262. [In Portuguese].

[30] Merhy EE. Em Busca do Tempo Perdido: a Micropolítica do Trabalho Vivo em Ato, em Saúde. In: Franco TB, Merhy EE. Trabalho, Produção do Cuidado e Subjetividade em Saúde. São Paulo: Hucitec Editora; 2013. p. 19-67. [In Portuguese].

[31] Lopes AS, Alves de Vilar RL, Melo RHV, França RCS. The hospitality in Primary Health Care: relations of reciprocity between workers and users. Saúde Debate 2015; 39(104):114-23.

https://doi.org/10.1590/0103-110420151040563

[32] Araujo TAM, Vasconcelos ACCP, Pessoa TRRF, Forte FDS. Multiprofessionality and interprofessionality in a hospital residence: preceptors and residents' view. Interface 2017; 21(62):601-13.

https://doi.org/10.1590/1807-57622016.0295

[33] Nascimento VL, Revorêdo SF, Nascimento EHL, Brasil DM, Freitas DQ, Lima GA. Burnout Syndrome among dental professors: a cross-sectional study. Rev ABENO 2018; 18(2):62-71. https://doi.org/10.30979/rev.abeno.v18i2.557

[34] Souza RS, Mendonça ALO, Rodrigues AMS, Felix EG, Teixeira LR, Santos MBM, et al. The new organization of labor at public universities: collective consequences of job instability on the health of teachers. Ciênc Saúde Coletiva 2017; 22(11):3667-76. https://doi.org/10.1590/1413-812320172211.01192016

[35] Neves CP, Ribeiro DM. Burnout in undergraduate dental students. Rev ABENO 2016; 16(1):39-49. https://doi.org/10.30979/rev.abeno.v16i1.232 